\title{
KONTRIBUSI KEBUGARAN JASMANI DAN MOTIVASI BELAJAR TERHADAP HASIL BELAJAR PESERTA DIDIK KELAS KHUSUS OLAHRAGA SEKOLAH MENENGAH PERTAMA NEGERI 1 KOTA BUKITTINGGI
}

\author{
Emil Mon ${ }^{1}$ Gusril $^{2,}$ Adnan Fardi ${ }^{3}$ \\ Email : emil29373@gmail.com
}

Based on obsevation at the Student of sport in SMP N 1 Bukittinggi City showed the learning outcomes is still low. This is estimated influence by pphysical fitness and learning motivatio. This study aims to know the contribution of physical fitness and learning motivation to learning outcames of student's Sport in SMP N 1 Bukittinggi City.

This reasearch medthod is correlation, to know how big the contribution one variable each other. The population are student of Sport in SMP N 1 BukittinggiCity in the academic year 2014/ 205 with amount 30 student. The sampling technique is total sampling, so the samples are 30 student. Data was collected by physical fitness test instrument Indonesia aged 13 to 15 year and completed questionnaires to measure physical fitnessand learning motivation, and learning outcomes used 2nd data of student's report in 2015/2016 acamic year.

The results showed that: (1) physical fitness had a significant contribution with $t_{\text {count }}(3,71)>t_{\text {table }}(1,70)$ and give contribution for $32,95 \%$ to learning outcomes. (2) Learning motivation had a significant contribution with $t_{\text {count }}(5,60)$ $>t_{\text {table }}(1,70)$ and give contribution for $52,85 \%$ to the learning outcomes. (3) physical fitness and leaning motivation have significant contribution with $\mathrm{F}$ count $(42,948)>F_{\text {table }}(3,35)$ And countributed together by $76.04 \%$ to learning outcomes.

Keywork: physical fitness, learning motivation, leanrning outcomes 


\section{PENDAHULUAN}

Program pemerintah dalam mewujutkan danmeningkatkan bidang keolahragaan diatur dalam Undang Undang Sistem Keolahragaan Nasional ( UU SKN) No:3 tahun 2005. Sebabagaimana yang termuat pada Bab II Pasal 4 Disebutkan bahwa:

"Keolahragaan nasional bertujuan memelihara dan meningkat kan kesehatan dan kegugaran, prestasi, kualitas manusia, menanamkan $\mathrm{n}$ ilai moral dan akhlak mulia, sportif,disiplin, mempererat dan membina persatuan dan kesatuan bangsa,memperkokoh ketahanan nasional, saerta meningkatkan harkat, martabat dan kehormatan bangsa".

Dalam pembahasan selanjutnya pasal 17 diatur pelaksanaan kegiatan olahraga ini secara lebih rinci kedaklam tiga ruang lingkup, yaitu: a. Olahraga Pendidikan, b. Olahraga Rekreasi, dan c. Olahraga Prestasi. Olahraga pendidikan merupakan salah satu upaya pemerintah dalam membentuk karakter peserta didik agar memiliki disiplin dan sportivitas yang tinggi, moral yang baik dan akhlak mulia,sehingga diharapkan mampu menjadi langkah awal untuk menjadikan olahraga sebagaiprestasi yang dapat mengharumkan harkat dan martabat bangsa.

Sebagai implementasi dari penjabaran dan pelaksanaan Undang Undang Sistem Keolahragaaan Nasional tahun 2005 tersebut,pemerintah telah melaksanakannya melalui beberapa jalur lembaga maupun instansi yang terkait langsung dalam pembangunan keolahragaan di Indonesia, diantaranya melalui jalur pendidikan, yang terkait langsung dsenganolahraga pendidikan pasal 18 ayat 2, Undang Undang Sistem Keolahragaan Nasional tahun 2005 yaitu olahraga pendidikan dilaksanakan baik pada jalur pendidikan formal maupun non formal melalui kegiatan intrakurikuler dan /aqtau ekstrakurikuler.

Untuk aspek olahraga pendidikan, saat ini pada jenjang pendidikan Sekolah Menengah Pertama (SMP) sudah terdapat wadah untuk membina calon atlet dari bangku pendidikan sekolah dengan adanya Kelas Khusus Olahraga (KKO) untuk meningkatkan prestasi olahraga nasional memlalui pembibitan calon atlet dari jenjang pendikan fermal. Hal ini kewajiban pemerintah melalui Direktorat Jendral Manajemen Pendidikan Dasar dan Menengah, Kementerian Pendidikan Nasional menyelenggarakan program kelas khusus olahraga pada jenjang pendidikan menengah, sejalan dengan itu dalam UU SKN tahun 2005 dalam pasal 32 ayat 1 , disebutkan bahwa pengelola sistim keolahragaan nasional merupakan tanggung jawab Menteri. Program ini diselenggarakan melalui Pilot Project di sekolah-sekolah menengah tertentu termasuk di SMP Negeri 1 Bukittinggi. Kelas Khusus Olahraga ini merupakan suatu kegiatan ko-kurikuler yanmg diharapkan dapat merningkatkan minat dan menyalurkan bakat peserta didik untuk menjadi atlet andlan yang didukung dengan program latihan yang disusun secara teratur sesuai dengan keadaan di sekolah. 
Kelas Khusus Olahraga ditingkat SMP ini adalah suatu kegiatan untuk membentuk wadah pengembangan potensi pesrta didik dalam bidang olahraga. Kebijakan tentang penyelenggaraan program kelas khusus olahraga ini bukanlah kebijakan yang lahir tanpa dasar, karena Undang-Undang Republik Indonesia no: 3 Tahun 2005 Tentang Sistem Keolahragaan Nasional, pasal 25 khususnya ayat 6 yang berbunyi: "untuk menumbuh kembangkan prestasdi olahraga di lembaga pendidikan, pada setiap jalaur pendidikan dapat dibentuk unit kegiatan olahraga, pusat pembinaan dan pelatihan, sekolah olahraga, serta diselenggarakaanya kompetisi olahraga yang berjenjang dan berkelanjutan". Hal tersebut dasar kebijakan tentang penyelenggaraan kelas khusus ini. KelaS Khusus Olahraga merupakan suatu kelas khusus yang diperuntukkan bagi peserta didik yang yang memiliki bakat dan prestasi pada cabang olahraga, disamping itu secara kurikulum peserta didik tetep mendapatkan pembelajaran seperti kelas lain pada umumnya.

Dalam prosesnya, kelas khusus olahraga mampu menhadirkan prestasdiprestasi pada iven pekan oloahraga pelajar yang mengangkat nama sekolah khususnya dan Bukittinggi pada umumnya, baik ditingkat antar sekolah dalam lingkungan kota Bukittinggi maupun di tingkat privinsi bahkan sampai tingkat nasaional. Dalam hal ini Peserta didik kelas khusus olahraga di bawah naungan SMP Negeri 1 Bukittinggi telah memunculkan beberapa nama Atlet yang masuk dalam tim POPNAS cabang olahraga Basket Sumatera Barat pada tahun 2013 dan pada tahun 2015, atas nama: Dhani Fajri dan Indah Helmadi bahkan Indah Helmadi setelah duduk dibangku SMA 1 Bukittinggi terpilih dalam tim Basket Nasional untuk berlatih Amerika Serikat yang sponsori oleh Honda, ajang yang diikuti untuk program ini melalui ajang seleksi yang sangat ketat dari seluruh Indonesia, bahkan Atlet yang berprestasi juga dapat kesempatan masuk sekolah paforit di kota Bukittinggi.

Adapun saat ini secara garis besar Kelas Khusus Olahraga di SMP Negeri 1 Bukittinggi terdapat dua kelompok kecabangan yaitu cabang Atletik dan cabang Bola Basket. Adapun pertimbangan kenapa dua cabang olahraga ini dijalankan pada program Kelas Khusus olahraga karena Atletik dan permainan bola Basket memiiki peminat palaing banyak dibanding dengan cabang olahraga lain yang boleh dikatakan kurang diminati oleh pesereta didik Kelas Khusus Olahraga. Melalui minat dan bakat yang dimiliki oleh peserta didik Kelas Khusus olahraga ini maka sejalan dengan kondisi tersebut sangat penting dikembangkan ranah psikomotor yang terdapat pada potensi diri peserta didik dalam menjadi individu yang unggul dan berprestasi sesuai bakat dan kemauannya serta beriringan dengan ranah kognitif dan ranah afektif.

Kelas Khusus olahraga sendiri merupakan kelas yang bertujuan untuk pembinaan dan peningkatan prestasi peserta didik dibidang 
olahraga. Dengan kondisi tersebut peserta didik Kelas Khusus olahraga harus dibina dan dilatih untuk menjadi seorang atlet yang berprestasi di tingkat daerah, nasional maupun internasional.

Kurikulum yang diterapkan di Kelas Khusus Olahraga sama dengan kurikulum yang di terapkan di kelas reguler tetap mengacu pada kurikulum 13. Untuk jam mata pelajaran akademiknya tetap sama dengan kelas reguler, akan tetapi untuk jam pembinaan aktivitas jasmani atau olahraganya ditambah.

Dalam prosesnya peserta didik sangat antusias dalam melaksanakan aktivitas keolahragaan yang dapat dilihat dalam Kelas Khusus olahraga dilakukan peserta didik dengam semangat dalam latihan sampai kepada perestasi-prestasi yang diraih dalam pertandingan, namun hal ini tidak berbanding lurus untuk mata pelajaran lainnya. Dari hasil observasi yang dilakukan terlihat bahwa hasil belajar peserta didik cukup rendah, ditemukan 21 orang( $60 \%$ ) peserta didik tidak memnuhi Kriteria ketuntasan Minimal (KKM) pada mata pelajaran pada umumnya terutama seperti Matematika, IPA Terpadu, IPS Terpadu dan mata pelajaran lainnya sehingga seringkali harus dilakukan remedial.

Menjadi persoalan bersama bagi orang tua dan guru dari pihak sekolah karena pandangan masyarakat terutama orang tua bahwa Kelas Khusus Olahraga merupakan program pendidikan yang masih baru, maka masih banyak masyarakat umum yang belum mengerti mengenai pemahaman tentang kelas khusus ini, mereka beranggapan bahwa Kelas Khusus Olahraga dirasa masih belum penting untuk diikuti oleh peserta didik, selain itu pelaksanaan atau pelatihan dalam Kelas Khusus olahraga dilaksanakan sesudah pembelajaran kelas reguler selesai atau tepatnya sesudah pulang sekolah, hal tersebut akan berdampak pada kondisi stamina peserta didik yang mudah kerlelahan dikarenakan setelah peserta didik mengikuti kelas reguler, mereka juga harus mengikuti kelas khusus tersebut.

Untuk mengatasi hal ini perlu dilakukan edukasi kepada masyarakat tentang pentingnya Kelas Khusus Olahraga dalam mengembangkan bakat dan potensi peserta didik dalam cabang olahraga, yang menjadi permasalahan yang utama bukanlah Kelas Khusus olahraga namun hal lain yang dapat mempengaruhi peserta didik.

Azwar (2012:13)Mengemukakan bahwa hasil belajar merupakan "hasil yang telas dicapai oleh peserta didik dalam belajar" Sedangkan menurut Sukmadinata (2004:102) hasil atau achievement merupakan realisasi atau pemekaran dari kecakapan - kecakapan potensial atau kapasitas yang dimiliki seseorang", Dari perndapat di atas dapat disimpulkan bahwa hasil belajar merupakan suatu hasil maksimal yang diraih oleh seseorang peserta didik sesuai dengan usaha, potensi dan kapasitas yang dimilikinya. 
Oleh karena itu, penting kiranya agar peserta didik mampu mendapatkan hasil belajar yang baik pada mata pelajaran lain di luar program kelas khusus olahraga agar peserta dfidik tidak tertinggal dan mampu menjawab keraguan masyarakat terutama orang tua, bahwa dalam program Kelas Khusus olahraga peserta didik seyokyanya mampu menyeimbangkan antara hasil belajar pada mata pelajaran umum dan pestasinya sendiri pada cabang olahraga masing-masing.

\section{Syahara}

(2003:62)Mengatakan

bahwa "Kebugaran jasmani merupakan kemampuan tubuh unutk melakukan kegiatan fisik dan psikis tanpa menderita kelelahan yang luar biasa dan masih memiliki tenaga untuk kegiatan fisik lainnya dalam mengisi yang masih luang".

Dengan demikian kebugaran jasmani merupakan tampilan dari keadaan kesehatantubuh dalam suasana segar atau nyaman, dengan memiliki kesegaran jasmani yang baik menggambarkan pula kesehatan tubuh yang baik secara menyeluruh. Hal ini juga mempengaruhi seseorang dalam proses pembelajaran terutama kognitif, dengan memiliki kesegaran jasmani yang baik, membantu peserta didik dalam menjalani proses pembelajaran dengan baik pula. Sebaliknya jika peserta didik mengalami rendahnya kesegaran jasmani, maka kecenderungan terlihat dari tampilan peserta didik secara fisik seperti tidak bersemangat dan mudah mengantuk dalam pembelajaran. Hal ini dikhawatirkan dapat m,epengaruhi hasil belajar peserta didik dan secara menyeluruh juga menurunnya produktifitas dalam kehidupan.

Demikian juga motivasi sebagaimana yang dinyatakan oleh Welodkowski dan Jaynes (2004:6) menyatakan motivasi belajar adalah "sebuah nilai dan hasrat untuk belajar" Motivasi belajar mempunyai peranan penting dalam memberikan rangsangan, semangat dan rasa senang dalam belajar sehingga yang mempunyai motivasi tinggi mempunyai energi yang banyak untuk melaksanakan proses pembelajaran. Selanjutnya menurut Uno (2012:23) motivasi belajar adalah, "Dorongan internal dan ekternal pada peserta didik yang sedang belajar untuk mengadakan perubahan tingkah laku.

Berdasarkan adanya permasalahan yang diungkapkan tersebut, maka penulis tertarik unutk mengetahui lebih jauh tentang Hasil Belajar Peserta didik Kelae Khusus Olahraga SMP Negeri 1 Bukittinggi dan sekaligus mengetahui seberapa besar konrtribusi Kesegaran Jasmani Peserta didik dan motivasi belajar peserta didik terhadap Hasil Belajar peserta deidik Kelas Khusus Olahraga di SMP Negeri 1 kota Bukittinggi.

\section{METODE PENELITIAN}

Sesuai dengan tujuan penelitian ini yaitu mengungkap besarnya kontribusi Kebugaran Jasmani dan Motivasi Belajar terhadap Hasil Belajar pada peserta didik Kelas Khusus Olahraga SMP Negeri 1 kota Bukittinggi, maka jenis penelitian ini adalah 
Penelitian Kuantitatif dengan menggunakan Metode korelasi.

Populasi dalam penelitian ini adalah seluruh Peserta didik Kelas Khusus Olahraga SMP Negeri 1 kota Bukittinggi yang berjumlah 30 orang. Teknik penarikan sampel dalam penelitian ini dilakukan dengan teknik total sampling, yaitu semua populasi dijadikan sebagai sampel. Jadi sampel dalam penelitian ini berjumlah 30 orang.

Untuk mengukur hasil belajar yang digunakan adalah dengan melihat nilai rapor peserta didik semester sebelumnya semester genap 2014/2015) yang mengacu kepada rata rata Nilai Ujian Harian (UH) yang berbobot $(60 \%)$, Nilai Ujian Mid semester yang berbobot (20\%) dan Nilai Ujian Akhir Semester yang berbobot (20\%) yang selanjutnya dikumpulkan disalin dari wali kelas Khusus Olahraga SMP Negeri 1 kota Bukittinggi.

Untuk merlihat tingkat kebugaran jasmani dilakukan tes TKJI. Dimana TKJI merupakan satu rangkaian tes,oleh karena itu semua butir tes harus dilaksanakan secara berurutan, terus-menerus dan tidak terputus dengan memperhatikan kecepatan perpindahan butir tes berikutnya dalam 3 menit. Perlu dipahami bahwa butir tes dalam TKJI Usia 13 - 15 tahun ini bersifat baku dan tidak boleh dibolak balik, dengan urutan pelaksanaan tes sebagai berikut: 1) Lari cepat 50 Meter; 2) Gantung angkat tubuh untuk putra (pull up), gantung siku tekuk untuk putri(menahan); 3) Baring duduk (sit up) ; 4)Loncat Tegak (vertical jump); 5)1000 meter (Putra), 800 meter (Putri).

Tes yang digunakan dalam mengukur motivasi belajar adalah angket tertutup yang berbentuk pilihan. Angket berbentuk pilihan adalah bentuk dimana jawabanya telah disediakan (closed ended item) .adapun angket yang digunakan adalah angket tertutup model skala Likert.

Teknik analisis data yang digunakan unutk menguji hipotesis 1 dan 2 dengan korelasi sederhana dan hipotesis 3 dengan korelasi ganda, serta dilanjutkan dengan menghitung besarnya kontribusi dengan koefisien determinasi $\left(r^{2} \times 100 \%\right)$. Menurut $J$. Supranto (2001:205) $r^{2}$ disebut koefisien determinasi ( coefficien of determination), yaitu nilai untuk mengukur besarnya kontribusi variabel bebes $(\mathrm{X})$ terhadap variasi (naik turunnya variabel terikat. Apabila besarnya kontribusi dihitung dalam bentuk persentase yang dapat dilambangkan $r^{2} \times 100 \%$.

Sebelum melakukan analisis terhadap data diatas, dilakukan Uji persyaratan Analisis, yaitu: Uji Normalitas, Uji Linieritas Regresi $\mathrm{X}_{1}$ atas $\mathrm{Y}$ dan $\mathrm{X}_{2}$ atas $\mathrm{Y}$ dan Uji Independensi antar variabel bebas.

\section{UJI PERSYARATAN ANALISIS}

Persyaratan yang diperlukan sebelum melakukan anlisis regresi linier sedrhana dan ganda meliputi Uji normalitas, Uji Linieritas dan Uji independen. 
Hasil perhitungan uji normalitas tersebut, secara lengkap dapat dilihat pada tabel berikut:

\begin{tabular}{|c|c|c|c|c|}
\hline No & $\begin{array}{c}\text { Varia } \\
\text { bel }\end{array}$ & $\begin{array}{l}\mathrm{L} \\
\mathrm{o}\end{array}$ & $\begin{array}{l}\mathrm{L}_{\text {tabel }} \\
\mathrm{aa}_{=0,0} \\
5\end{array}$ & Ket \\
\hline 1 & $\begin{array}{l}\text { Kebu } \\
\text { gara } \\
\mathrm{n} \\
\text { jasm } \\
\text { ani } \\
\left(\mathrm{X}_{1}\right) \\
\text { terha } \\
\text { dap } \\
\text { hasil } \\
\text { belaj } \\
\text { ar }(\mathrm{Y})\end{array}$ & $\begin{array}{l}\text { 옹 } \\
\text { 음 }\end{array}$ & $\begin{array}{l}0,16 \\
1\end{array}$ & $\begin{array}{l}\text { Norm } \\
\text { al }\end{array}$ \\
\hline 2 & $\begin{array}{l}\text { Motiv } \\
\text { asi } \\
\text { belaj } \\
\text { ar } \\
\left(X_{2)}\right. \\
\text { Hasil } \\
\text { Belaj } \\
\operatorname{ar}(Y)\end{array}$ & $\begin{array}{l}\text { P } \\
\text { ㅇ } \\
\frac{0}{0}\end{array}$ & $\begin{array}{l}0,16 \\
1\end{array}$ & $\begin{array}{l}\text { Norm } \\
\text { al }\end{array}$ \\
\hline
\end{tabular}

Selanjutnya hasil perhitungan Uji Linieritas dapat dilihat pada tabel berikut:

Tabel. Rangkuman Hasil Uji Linieritas Variabel Kebugaran Jasmani (X1) Motivasi Belajar (X2) terhadap (Y)

\begin{tabular}{|l|l|l|l|}
\hline Variab & $\mathbf{F}$ & $\mathbf{F}$ & Kesimp \\
el & hit & Tab & ulan \\
un & el & \\
$\mathbf{g}$ & $a_{=0.5}$ & \\
\hline $\mathrm{X} 1-\mathrm{Y}$ & $\begin{array}{l}1.5 \\
6\end{array}$ & 2.43 & Linier \\
\hline $\mathrm{X} 2-\mathrm{Y}$ & $\begin{array}{l}2.7 \\
7\end{array}$ & 2.82 & Linier \\
& & \\
\hline
\end{tabular}

Hasil analisis korelasi jenjang Motivasi Belajar dapat dilihat pada tabel berikut;

\section{Tabel Uji Signifikansi Korelasi X1 dengan X2}

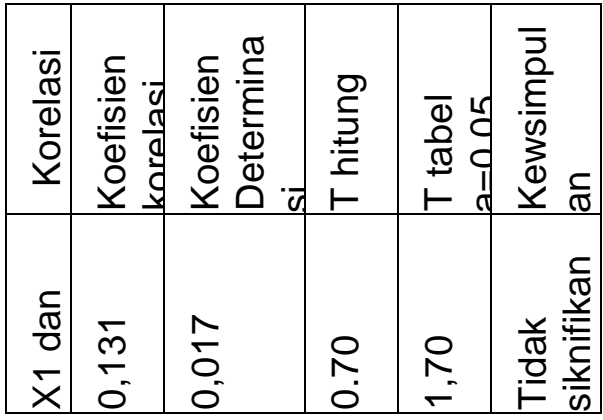

\section{HASIL PENELITIAN DAN PEMBAHASAN}

Hipotesis pertama, dari hasil analisis diperoleh persamaan regresi $Y=70.00+1.15$ $X$. Model persamaan regresi ini mengandung arti bahwa apabila kebugaran jasmani ditingkatkan pada satu skor, maka kecenderungan hasil belajar meningkat sebesar 1,15 pada konstanta 70,00. Berdasarkan analisis data, telah terbukti bahwa kebugaran jasmani memiliki kontribusi yang siknifikan dan positif terhadap hasil belajar pada taraf signifikan $\mathrm{a}=0,05$ terlihat pada analisis korelasi parsial artinya kebugaran jasmani memiliki hubungan positif yang siknifikan dan memberikan kontribusi yang berarti terhadap hasil belajarsebesar 32,95 \%. 
Hipotesis penelitian ke 2 penliti temukan motivasi berlajar berkontribusi terhadap hasil belajar.

Untuk mengetahui kontribusi antar variabel dimana skor pada suatu variabel dapat digunakan unutk memprediksi skor pada variabel lainnya juga dilakukan analisis regresi linier sederhana. Dari hasil analisis diperoleh persamaan regresi

$Y=28.70+\hat{0,52 X}$. Model persamaan rekresi ini mengandung arti bahwa apabila motivasi belajar ditingkatkan maka satu skor, maka kecenderungan hasil belajar meningkat sebesar 0,52 pada konstanta 28,70.

Berdasrkan analisis data diatas, telah terbukti bahwa motivasi belajar memikliki hubungan siknifikan dan positif terhadap hasil belajar pada tarf siknifikan $a=0,05$, Hal ini terlihat pada analisis korelasi parsial dengan memberikan kontribusi yang berarti terhadap hasil belajarsebesar $52,85 \%$

Uji hipotesis ketiga yaitu kebugaran jasmani dan motivasi belajar secara bersama sama memiliki kontribusi terhadap hasil belajar.berdasrkan hasil penelitian ditemukan kebugaran jasmani dan motivasi belajar secara bersamasama memiliki hubungan secara siknifikan terhadap hasil belajar dengan koefisien determinasi76,04\%

Untuk mengetahui kontribusi antar fariabel dimana skor pada suatu variabel dapat digunakan untuk memprediksi skor pada variabel lainnya dilakukan analisis regresi linier sederhana. Dari hasil analisis persamaan regresi

$\mathrm{Y}=21.04 \hat{\imath} 0.98 \mathrm{X} 1+0.47$ X2 Model persamaan reresi ini mengandung arti bahwa apabila kebugaran jasmani dan motivasi belajar ditingkatkan pada satu skor maka kecenderungan hasil belajar sebesar meningkat 0,98 padaX1 dan 0,47 padaX2 pada konstanta 21,04

\section{KESIMPULAN DAN SARAN}

Berdasarkan hasil analisis data dan pembahasan yang telah dijelaskan pada bab sebelumnya, maka dapat diambil kesimpulan sebagai berikut;

1. Kebugaran jasmani memiliki kontribusi yang siknifikan terhadap hasil belajar yang ditandai dengan peroleh $\mathrm{t}$ hitung $=3,71<\mathrm{t}$ tabel $=1,70$, kemudian dilihat lebih murni lagi hubungannya melalui korelasi sederhana $r$ hitung $=0,574>r$ tabel=0,361 dan berkontribusi terhadap peserta didik Kelas Khusus Olahraga SMP Negeri 1 kota Bukittinggi sebesar $32,95 \%$.

2. Motivasi belajar memiliki kontribusi yang siknifikan terhadp hasilbelajar ditandai denganperoleh $\mathrm{t}$ hitung $=5,60>\mathrm{t}$ tabel= 1,70 , kemudian dilihat lebih murni lagi hubungannya melalui korelasi sederhana $r$ hitung $=0,727>r$ tabel $=0.361$, dan berkontribusi terhadap Peserta didik Kelas Khusus olahraga SMP Negeri 1 kota Bukittinggi sebesar 52,85\%.

3. Kebugarasn jasmani dan motivasi belajar secara bersama-sama memiliki kontribusi terhadap hasil belajar yang ditandai dengan peroleh $F$ hitung $(42,948)>F$ tabel $(3,35)$, kemudian dilihat lebih murni lagi hubungannya melalui korelasi ganda diperoleh $r$ hitung $=0,873>r$ tabel $=$ 0,361 , dan berkontribusi terhadap peserta ddik Kelas Khusus Olahraga SMP Negeri 1 kota Bukittinggi saebesar $76,04 \%$

Dalam upaya peningkatan hasil belajar peserta didik Kelas Khusus Olaharaga SMP Negeri 1 kota Bukittinggi, diharapkan;

Para guru agar menumbuhkan potensipotensi Peserta didik berminat untuk menjaga kebugaran jasmani dan 
mendapatkan prestasi hasil belajar khususnya. Setelah itu agar membantu peserta didik nya dalam mengembangkan potensi yang dimiliki atau sebagai pengontrol kegiatan peserta didiknya di sekolah dan menggunakan gaya mengajar yang menyenangkan, sehingga peserta didik termotivasi dalam mengikuti pembelajaran.

Bagi sekolah, sebagai masukan dalam merencanakan, melaksanakan dan mengembangkan potensi peserta didik disekolahnya dan sebagai strategi untuk menunjang keberhasilan dalam hasil belajar peserta didik.

Bagi Peserta didik, supaya dapat meningkatkan potensi yang dimilikinya melalui aspek fisiologi (kebugaran jasmani) dan aspek Psikologi( motivasi belajar) sehingga diharapkan dapat memperoleh hasil belajar yang baik.

Peneliti berikutnya akan meneliti dengan variabel yang lebih banyak. Disebabkan peneliti yang dilakukan santlah terbatas dari segi variabel, jumlah sampel, tempat dan waktu penelitian. Maka diduga masih banyak variabel lain yang turut mendukung terhadap hasil belajar.

\section{DAFTAR RUJUKAN}

Azwar, Saifudin. 2012. Sikap Manusia Teori dan Pengukurannya, Yokyakarta: Pustaka Pelajar.

Sukmadinata, Nana Syaodih. 2003. Landasan Psikologi Proses Pendidikan

Bandung: Remaja Rodaskarya

Syahara Sayuti. 2003. Konsep Rangkuman dan Penjelasan. The Physiological bhasis of Physical education and Atletics. Padang Pascasarjana UNP.
Undang Undang Repuplik Indonesia No:3.2005. UU Tentang Sistem keolahragaan Nasional. Jakarta: Kementerian pemuda dan Olahraga.

Uno, Hamzah B. 2012. Teori Motivasi dan Pengukurannya. Jakarta: Bumi Aksara

Wlodkowski, Raymond J. \& Judith H Jaynes.2004. Motivasi Belajar, Jakarta: Cerdas Pustaka 
Jurnal Menssana

ISSN : 2527-645X

Vol. 2, NO. 2, Mei 2017 